\title{
SOLAR ENERGY APPLICATION IN WASTE TREATMENT- A REVIEW
}

\author{
B. O. Ugwuishiwu ${ }^{1,{ }^{*}, \text { I. P. Owoh }}{ }^{2}$ and I. J. Udom ${ }^{3}$ \\ 1DEPARTMENT OF AGRICULTURAL \& BIORESOURCES ENGINEERING, UNIVERSITY OF NigERIA, NSUKKA, ENUGU STATE, NIGERIA

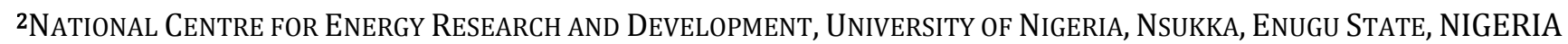

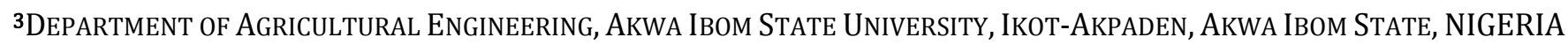 \\ E-mail addresses:1 boniface.ugwuishiwu@unn.edu.ng, ${ }^{2}$ ikennarock@yahoo.com,3ikpeudom@aksu.edu.ng
}

\begin{abstract}
This review is an exposure on the various ways that solar energy can be harnessed for numerous waste treatment processes. Almost all forms of waste treatment require energy which is scarcely available considering the global energy crisis. The objective of this study is to enumerate the solar energy applications in waste treatment as a way of global environmental protection and energy management. Solar energy which is abundant in most part of the world has been adopted as a very sustainable source of energy for waste treatment. Its application in both solid waste and waste water treatment as in pyrolysis, solar incineration and gasification for solid wastes treatment and solar pathogenic organic destruction, solar photocatalytic degradation, solar distillation and desalination for waste water treatment. These waste treatment methods require light from the sun to photocatalyse reactions and also heat as thermal energy for the various endothermic reactions. This review therefore highlighted various methods of waste treatment which does not require the limited conventional energy sources. It also reveals that model optimizations for assessing the best options for potential pollutant treatment in pyrolysis, solar incineration, gasification, photo catalytic degradation etc, of contaminants have not been achieved.
\end{abstract}

Keywords: Waste treatment, Solar, Photocatalysis, Distillation, Pyrolysis, Gasification.

\section{INTRODUCTION}

Waste management has emerged as one of the greatest challenges facing developing countries. The volume of waste been generated has continually increased as global population is increasing and resources available cannot adequately handle it [1]. According to [2], inadequate access to clean water and lack of its sanitation are persistent world-wide problems affecting humans on each continent (according to United Nations, number of people who lack access to safe drinking water will increase from over 1 billion to over 1.8 billion in 2025). Water may seem to be abundant on our planet but not readily assessable. In fact, less than $1 \%$ of world potable water is available for immediate human consumption and even that is not uniformly distributed around the globe [3]. This implies that proper waste water management is a good way of bridging the water demand supply gap and this inevitably could be achieved using renewable energy on both environmental and cost grounds [4] to aid the supply of clean water. Renewable energy sources are being promoted for a wide variety of applications worldwide including waste treatment. Renewable energy does not contribute to any form of pollution and is a capable substitute for convectional fuels in most of the applications. While many laboratory studies have demonstrated the feasibility of the method of photocatalytic detoxification for almost all classes of hazardous chemicals, almost all of these studies have been directed towards the oxidative degradation of organic pollutants in water. Life in modern societies is inevitably related to waste generation. The effective management of solid waste involves the application of various treatment methods, technologies and practices. All applied technologies and systems must ensure the protection of the public health and the environment. Waste engineering and waste management technologies have become so important due to increase in rate and diversity in both quantity and quality of waste that is being generated daily. Waste generation is closely linked to population, urbanization and affluence [5] Also the need for environmental protection and the economic 
importance of converting waste to wealth by solid waste recycling and waste water treatment using the most economically feasible methods have become so important and necessary. Solid waste especially those from house hold could be regarded as a source of renewable energy because it contains a high proportion of biomass materials which could be degraded catalytically [6] or thermally in absence of air (pyrolysis) or limited air (Gasification) to produce a mixture of combustible and non-combustible gases as well as pyroligneous liquid of high heat value. This liquid when further processed could be utilised as liquid fuel for burning in a boiler or as a substitute for diesel in reciprocating engines [7]. Waste generation cannot be totally eliminated hence the option of waste treatment has become so distinctively relevant because a lots is being expended in its management. In trying to reduce the cost of waste treatment by method cost reduction, numerous solar energy based applications were proffered as solution for both waste water and solid waste management. The objective of this study is to review the solar energy applications in waste treatment as a way forward in terms of waste management, renewable energy utilization, waste-toenergy conversion, climate change mitigation and most importantly environmental protection.

\subsection{Meaning of Waste}

Waste as the name implies, traditionally is referred to as something useless and valueless. Waste always comes as the by-product of systems, industries, households etc. By definition, waste could be ascribed to an unwanted material or unusable item, remains, byproduct or household garbage. From the definition, wastes are perceived as being unproductive and unwanted product from industries and household. The quantity or volume of waste generated is largely dependent mainly on two factors namely: the population in any given area and the consumption pattern of the inhabitants of such area. The increase in waste generation rate and diversity is as a result of population increase and changing in consumption pattern, economic developments, changes in income level and urbanization. In other words, Waste is mainly a by-product of consumer-based lifestyles that drive much of the world's economies [8]. Waste like every other matter could be found in the form of liquid, solid or gas.
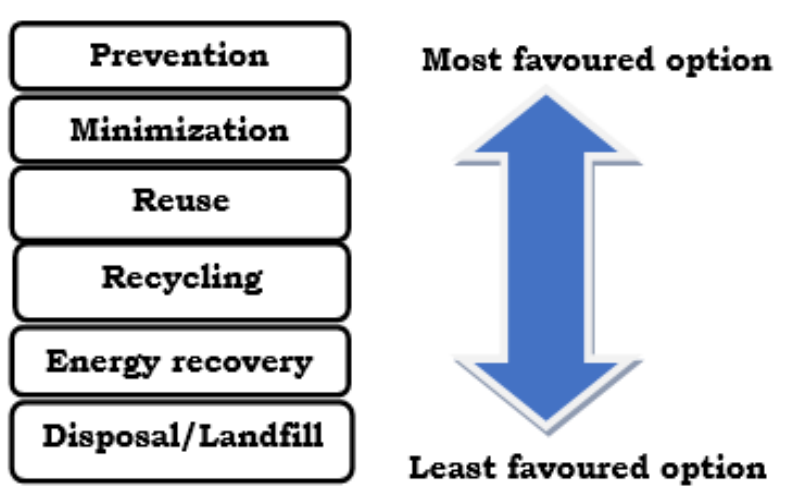

Figure 1: Illustrates the concepts of waste management

\subsection{Concept of Waste Management}

Waste management is the practice and procedure or the administration of activities that provide for the collection, separation, storage, transportation, transfer, processing, treatment and disposal of waste [9]. The generation of waste cannot be totally eliminated; neither can waste recycling be achieved completely. So there is always the need for waste management. The concept of waste management becomes very important because of the need to prevent the contact between humans and waste and as well to protect the immediate environment and safeguard individuals, families and community health. Proper waste management adds to the aesthetic value of the environment which is very important for, social, psychological and emotional well-being. The concept of waste management is highly dependent on the form of waste. The principle and methods adopted in the treatment of solid wastes are far more different from that adopted in the treatment of liquid and gaseous wastes. Though the nature and composition of waste generated in an area varies as a function of the level of development, life style and income of the inhabitants just like it varies across the countries [10]. The wastes generated in developed countries are mainly inorganic in nature, whereas organic contents form a large portion of waste in developing countries [10-13]. The most compatible environmentally sustainable development approach to waste is the "Integrated Waste Management" [14, 12, and 11]. According to [9] integrated approach to waste management consists of a "hierarchical and coordinated set of actions" [11] seeks to reduce pollution, maximize recovery of reusable and recyclable materials, and protects human health and the environment. The concept of waste management could be summarized to mean methods and steps taken to: Reduce the quantity of waste that is being generated or even to stop its generation 
completely; To recycle the waste with the aim of reuse or if possible reclaim the useful components of the waste where reuse is not possible; Treatment of the unreclaimed components of the waste and Proper disposal of residues to air, water or land. Figure 1 is the structural representation of the above discussed concept of waste management.

\subsection{Meaning and Origin of Solar Energy.}

Solar energy can simply be defined as energy from the sun. The sun is considered to be a fusion reactor. Its continuous fusion reaction is responsible for the heat energy radiated by it [15]. This radiated energy can travel infinite distances to nearby planets such as earth or planets millions of light years away. It emits $4 \times 10^{26} \mathrm{~W}$ of energy of which only $1.7 \times 10^{17} \mathrm{~W}$ reaches the earth [16]. This means that the earth receives less than one billion of the suns power output. The sun is humanity's oldest energy source. Scientists and engineers have sought to harness the power of sunlight for a wide range of heating lighting and industrial applications. The science of the solar energy and systems has no exact date of its inception but as far back as the $2^{\text {nd }}$ century A.D, the earliest attempts were made by the Greeks to explain the kinematics of the solar system of which they were able to develop the geocentric or Ptolemaic scheme for the solar system [17]. Nicolaus Copernicus in the sixteenth century replaced the geocentric scheme with a heliocentric or Copernican scheme. This Copernicus concept laid the foundation for the development of our modern view of the solar system and utilized in the design of solar energy equipment.

\subsection{Solar Energy Application in Waste Water Treatment} In line with [18], Wastewater treatment processes could be basically divided into 3 groups: mechanical, chemical and biological. These treatment methods are used in various combinations depending on the type and concentration of pollutants. Solar energy could be applied directly or indirectly in any of these treatment processes. The need for the application of solar energy in waste water treatment is justified by: the importance of clean water for both industrial and domestic activities, the abundance of solar radiation on the earth surface, the need to minimize wastage in both the industrial and domestic sectors, for energy and resource efficient operations.

The applications that involves solar energy in waste water treatment are as follows

\subsubsection{Solar Distillation and Desalination of waste water} Water distillation is a typical mechanical/physical separation method which is achieved by evaporation and condensation processes. Solar distillation involves the use of solar energy to achieve distillation. In simple solar water stills, a solar collector which traps the solar radiation and converts it to heat is used to evaporate the water contained in the distillation chamber of the still. The evaporated water as a result of saturation in the chamber condenses on the trapping side where the condensed water now passes through a funnel shaped hopper to the distillate storage tank. Solar distillation can be used to make salty water potable (desalination). The first recorded instance of this was by 16th-century Arab alchemists. A large-scale solar distillation project was first constructed in 1872 in Chile with the plant which had solar collection area of $4,700 \mathrm{~m}^{2}$, and was able to produce up to 22,700Litres per day [19]. Water still designs include single-slope, double-slope (or greenhouse type), vertical, conical, inverted absorber, multi-wick, and multiple effect [20]. These stills can operate in passive, active, or hybrid modes. Doubleslope stills are the most economical for decentralized domestic usage. The active multiple effect units are more suitable for large-scale applications.

\subsubsection{Solar Pathogenic Organic Destruction}

Pathogenic organic destruction otherwise known as disinfection is a biological treatment method. It is a waste-water treatment method that could be achieved using solar radiation. It is being referred to as solar disinfection (SODIS). This was developed in the 1980's to inexpensively disinfect water used for oral dehydration solutions for treatment of diarrhea [21]. SODIS has been proven to improve water quality and reduce diarrhea incidence in developing countries where sophisticated water purification methods are not available, it revealed a great potential to reduce the global diarrheal diseases burden, which affects over 1.8 million people [22,23]. Solar disinfection is achieved by filling about 0.3-2.0 litre plastic bottles with low turbidity water, shaking the water to oxygenate and then place under the sun for six hours but if the weather is cloudy, then it should be left for about 2 days. The combined effect of UV-induced DNA alteration, thermal inactivation, and photo-oxidative destruction (POD), inactivates the disease causing organisms in the water. According to [22] more than 2 million users currently practice SODIS in 33 countries. 
SODIS is a virtually zero cost technology that does not require any formal training for its application.

\subsubsection{Solar photocatalytic degradation (SPD)}

Another application of solar energy in waste water treatment is the utilization of solar UV radiation for photo catalytic oxidation. Photocatalysis is the combination of photochemistry and catalysis, a process where light and catalysis are simultaneously used to promote or accelerate a chemical reaction. It could be defined as a catalysis driven acceleration of a light induced reaction [24]. Photocatalysis appears as an excellent tool for final treatments of samples containing persistent organic pollutants (POPs) when compared to classical treatments $[25,26]$.

Solar catalytic oxidation (SCO) involves generation of highly reactive radicals especially hydroxyl radicals that degrade a wide range of organic contaminants present in waste water in presence of a semiconductor catalyst and UV radiation. In this oxidation application, the purpose is to cleanse the industrial waste water for purposes like irrigation and other domestic uses.

This heterogeneous photocatalytic oxidation which is an advanced oxidation process (AOP) has proved to be a promising technology for remediation of organic pollutants in water at ambient conditions [27] and improvement and maintenance of water quality [2831]. The photocatalytic reactions occur when charge separation are induced in a large band gap semiconductor by excitation with ultra violet radiation as shown below.

Organic Molecule $+\mathrm{O}_{2} \underset{\text { Catalyst }\left(\mathrm{Ti}_{2}\right)}{\longrightarrow} \mathrm{CO}_{2}+\mathrm{H}_{2} \mathrm{O}+$

Mineral Acids

This method has the advantage of complete destruction of organic pollutant when compared with other established water purification processes though it is not rapid in action and not easy to use or maintain. The use of advanced oxidation processes for waste water treatment has been studied extensively, but UV radiation generation by lamps or ozone production is expensive [32], thereby necessitating the applications of these processes with the use of catalysis and solar energy. Therefore, research is focusing more and more on those advanced oxidation processes which can be driven by solar irradiation, photo-Fenton and heterogeneous catalysis with $\mathrm{UV} / \mathrm{TiO}_{2}$ [33]. Several reviews have appeared during the last few years [34-40]. The equipment for photocatalytic applications is similar to the conventional solar thermal collector with the following main differences. The fluid must be exposed to the ultraviolet solar radiation. The absorber must be transparent to enable the penetration of the radiation. No thermal insulation is applied since temperature does not play any important role in the process. A view of a typical Solar photo Reactor is as shown Figure 2 below.

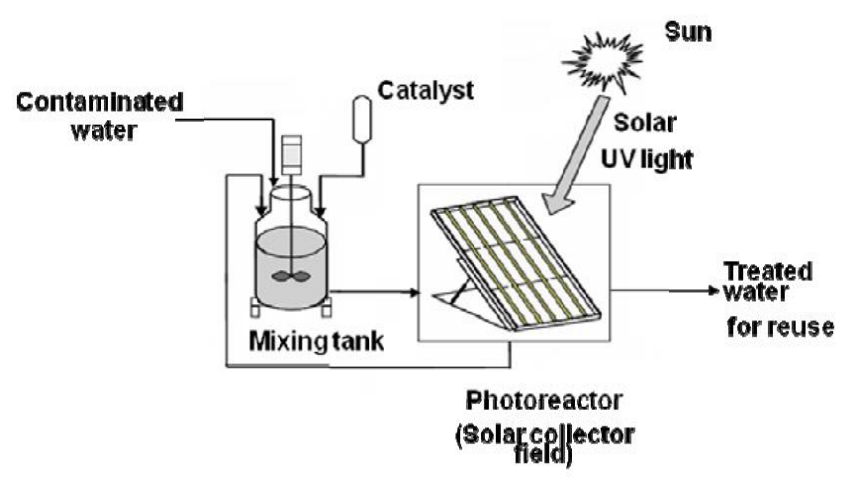

Figure 2: Solar Photo Reactor Adopted from [27]

This form of advanced oxidation reaction that is utilized in the treatment of organic pollutants, classified as bio-recalcitrant, (not biodegradable) is a photocatalytic degradation. It is applied in water treatment technologies for organic pollutants not treatable by conventional techniques due to their high chemical stability and/or low biodegradability [41, 42]. These processes involve generation and subsequent reaction of hydroxyl radicals $(\bullet \mathrm{OH})$, which are one of the most powerful oxidizing species. Many oxidation processes, such as $\mathrm{TiO}_{2} / \mathrm{UV}, \mathrm{H}_{2} \mathrm{O}_{2} / \mathrm{UV}$, Photo-Fenton and ozone $\left(\mathrm{O}_{3}, \mathrm{O}_{3} / \mathrm{UV}, \mathrm{O}_{3} / \mathrm{H}_{2} \mathrm{O}_{2}\right)$ are used for this purpose. Their attack is not very selective, which is a useful attribute for use in pollution treatment. The versatility of AOPs is also enhanced by the fact that there are different $\bullet \mathrm{OH}$ radical production possibilities, so they can be adapted to specific treatment requirements. Solar photocatalysis is a degradation reaction that aims at mineralizing the contaminants in waste water into carbon dioxide, water and in organics [43]. Pollutants that were efficiently mineralized by photocatalysis are effluents from industries containing dyes [44], pesticides [45, 46] and the effluents from the paper industry [47].Various applications are also known for the decontamination of waste gases $[48,49]$ including those involving self-cleaning surfaces [50] which is applied mostly in the treatment of industrial waste. In photocatalytic degradation, the parent organic compound is transformed to eliminate its toxicity and 
persistence. The carbon atom is oxidized into $\mathrm{CO}_{2}$.Other inorganic elements like nitrogen are mineralized mostly into $\mathrm{NO}_{3-}$ and $\mathrm{NH}_{4+}$. Though according to [51], Ammonium ions are relatively stable, and the proportion depends mainly on the amount of oxidation of organic nitrogen and irradiation time. Organophosphorous contaminants (mainly pesticides) produce phosphate ions. At the $\mathrm{pH}$ range used (usually $<4$ ), phosphate ions remain adsorbed on $\mathrm{TiO}_{2}$ if used as the oxidizing specie. This strong adsorption somewhat inhibits the reaction rate, though it is still acceptable [52]. Aromatic compounds are degraded to aliphatics. However, as concentration and number of contaminants increase, the process becomes more complicated and creates problems of slow kinetics caused mainly by low photo efficiency [43].

Solar energy is applied in (SPD) by the concentration of solar radiation just like every other solar photochemical process that uses only high-energy short-wavelength photons. There are two advanced oxidation processes that enable the use of sunlight as energy source. The two are heterogeneous photocatalysis using semiconductors and homogeneous photocatalysis using photo-Fenton processes $[53,54]$. $\mathrm{TiO}_{2}$ photocatalysis uses UV or near-UV sunlight (300 to $400 \mathrm{~nm}$ ) and photo-Fenton heterogeneous photocatalysis uses sunlight up to 580 $\mathrm{nm}$. The concentration is achieved by use of line focus concentrators like the parabolic trough collector or the compound parabolic concentrator which is the preferred collector for this purpose because they combine the characteristics of both parabolic concentrators and flat plat collector systems.

\subsubsection{Combining Solar Photocatalysis and Bio Treatment}

Apart from developments increasing the photocatalytic reaction rate, the most important progress in solar photocatalysis in recent years has been related to its combination with biological treatment and the application of toxicological analytical methods [43]. Both approaches have been successful in decreasing treatment time (i.e. plant size), which is another way of increasing overall process efficiency, in contrast to increasing the reaction rate itself. The combination reduces treatment time and optimizes the overall economics, since the solar detoxification system can be significantly smaller [55-57].

\subsection{Solar Energy Applications in Solid Waste Treatment} As a way of reducing the cost of solid waste management and to utilize the abundant solar radiation on the earth surface, numerous solar based solid waste treatments and conversion methods have been developed. Solar energy is used in processing of solid wastes on several stages of treatment. PV panels can also be used for generating electrical power for the waste treatment devices. Most commonly applied is the utilization of solar thermal power to maintain or increase the temperature required for the waste treatment process. Solar energy is used in the process of gasification of wastes of high carbon content, steam-gasification of biomass using concentrated solar energy to convert solid biomass feedstock into high-quality synthesis gas (syngas) used for power generation in efficient combined cycles and fuel cells, or for Fischer-Tropsch processing of liquid biofuels [58-60]. Conventional auto-thermal gasification is a highly endothermic reaction [61] which could be achieved by concentration of solar power. Also, the solar driven gasification eliminates the need for a pure stream of oxygen [60]. Solar-driven steam-gasification is free of nearly all combustion by-products and produced syngas has a lower amount of $\mathrm{CO}_{2}$ (calorific value is over that of the original feedstock by an amount equal to the enthalpy change of the reaction). Other methods include solar incineration and pyrolysis. Pyrolysis and gasification are similar processes they both decompose organic waste by exposing it to high temperatures and low amounts of oxygen. Gasification uses a low oxygen environment while pyrolysis allows no oxygen. These techniques use heat and an oxygen starved environment to convert carbonaceous material into other forms. All these methods are discussed in details in the subsequent sections

\subsubsection{Solar Incineration of Solid Wastes}

Solar energy is applied in waste management as solar incineration systems. In solar incineration, Hazardous and Non-hazardous liquid and solid wastes are incinerated. This is achieved by passing the waste through the heat collector chamber of a concentrating solar collector which generates high temperature on the waste. This is an economical application with Solar Thermal technology. With advance solar concentrated technology a temperatures up to $1000^{\circ} \mathrm{C}$ is achieved. The parabolas concentrate the solar radiations in the combustion chamber and air is circulated in the chamber, which keeps the temperature uniform 
throughout the chamber. Hazardous waste ranging from bio to chemical to municipal can be incinerated in the chamber. Applications of solar incinerators are found in Municipal Corporations for Municipal Solid Waste, Remote villages facing Solid waste problems, Hospitals, Military and Paramilitary forces for incinerating human and kitchen waste, Common effluent treatment plants, process plants and all the Industries generating hazardous Liquid or Solid waste.

\subsubsection{Solar Solid Waste Pyrolysis}

Pyrolysis is the thermal degradation of carbon-based materials through the use of an indirect, external source of heat, typically at temperatures of $450^{\circ} \mathrm{C}$ to $750^{\circ} \mathrm{C}$, in the absence or almost complete absence of free oxygen. It also involves the thermal degradation of organic waste in the absence of free oxygen to produce a carbonaceous char, oils and combustible gases. It is an endothermic thermochemical process taking place under inert atmosphere [62]. This degradation drives off the volatile portions of the organic materials, resulting in generation of a syngas composed primarily of $\mathrm{H}_{2}, \mathrm{CO}, \mathrm{CO}_{2}, \mathrm{CH}_{4}$ and complex hydrocarbons. Low-temperature pyrolysis can also be used to produce synthetic diesel fuel from waste. The syngas can be utilized in bgas turbines or internal combustion engines to generate electricity. The balances of the organic materials that are not volatile are left as char material. Inorganic materials form bottom ash that requires disposal, although some pyrolysis ash is used for manufacturing brick materials. Pyrolysis is an age-old technology but its application to biomass and waste materials is a relatively recent development [63]. An alternative term for pyrolysis is thermolysis, which is technically more accurate for biomass energy processes because these systems are usually starved-air rather than the total absence of oxygen [63]. All the products of pyrolysis are useful but the most important is the pyrolysis oil which is the main fuel for power generation. Solar energy is applied in solar thermal pyrolysis process where concentrated solar energy is deployed to drive at least part of the endothermic pyrolysis reactions [64].

\subsubsection{Solar Solid Waste Gasification}

Gasification is the thermal process that converts carbon-containing materials, such as coal, biomass, sludge, domestic solid wastes etc. to syngas which can then be used to produce electric power, and other valuable products like fertilizers. Gasification is a thermal reaction of hydrocarbons with limited oxygen. According to [63], gasification is a partial oxidation process which produces a composite gas (syngas) comprised primarily of hydrogen $\left(\mathrm{H}_{2}\right)$ and carbon monoxide (CO). The main reactions taking place during gasification are:

Oxidation (exothermic) $\mathrm{C}+\mathrm{O}_{2} \rightarrow \mathrm{CO}_{2}$

Water evaporation reaction (endothermic)

$\mathrm{C}+\mathrm{H}_{2} \mathrm{O} \rightarrow \mathrm{CO}+\mathrm{H}_{2}$

$\mathrm{CO}+\mathrm{H}_{2} \mathrm{O} \rightarrow \mathrm{CO}_{2}+\mathrm{H}_{2}$ (exothermic)

Boudouard Reaction (endothermic)

$\mathrm{C}+\mathrm{CO}_{2} \rightarrow 2 \mathrm{CO}$

Methane formation reaction (exothermic)

$\mathrm{C}+2 \mathrm{H}_{2} \rightarrow \mathrm{CH}_{4}$

The aim of gasification as a waste treatment process is to convert the feed material into more valuable, environmentally friendly intermediate products that can be used for chemical, fuel, and energy production. The gasifier operating temperature ranges from 1,400-2,800 degrees Fahrenheit [63]. This heat of reaction could be generated using a black cavity absorber to absorb concentrated solar radiation. The concentrated solar power system raises the temperature of the internal chamber of the gasifier to the proper reaction level. This method produces sufficient heat energy to perform the conversion reaction of solid carbonaceous fuels which includes biomass, coal, municipal solid waste or sewage sludge into syngas. This method of biomass gasification using solar energy produces higher yield of syngas when compared to the traditional combustion methods. In the application of solar energy for biomass gasification, the benefits include.

(a) 30 to 50 percent higher yield of fuel per unit feed stock, compared to traditional gasifier.

(b) Biomass does not need to be pulverized prior to entering the reactor.

(c) Operates at lower temperature and higher efficiency than the traditional gasifier.

\section{CONCLUSION}

This study highlights application of solar energy in both solid waste and waste water treatment as in pyrolysis, solar incineration, gasification for solid wastes treatments and solar pathogenic organic destruction, solar photocatalytic degradation, solar distillation and desalination for waste water treatments. Solar energy application in waste water management guarantee the availability of water for various agricultural and industrial purposes and reduces sicknesses by deactivating disease causing 
organisms in water for domestic purposes. It also protects the environment by abating pollution when utilized in advanced oxidation processes (AOPs) to treat waste before disposal. The application of solar energy in solid waste incineration, biowaste gasification and pyrolysis is a viable solar thermal practice which will ensure generation of renewable energy from wastes. Based on the above reasons, solar energy is thereby recommended for application in waste management. The expensive generation of UV radiation by lamps could be avoided by using solar UV which when applied in photocatalytic degradation of organic pollutants, yields a more excellent result when compared with classical waste water treatment methods. Therefore further studies should tend towards development of a low cost solar photo reactor with the intention of making water treatment a common practice.

This study reveals that model optimization for assessing the best option for potential pollutant treatment in pyrolysis,, solar incineration, gasification, photo catalytic degradation of contaminant has not been achieved. Despite its obvious potential for the detoxification of polluted water, there has been very little commercial or industrial use of photocatalysis as a technology to date.

\section{REFERENCES}

[1] Babatunde B. B, Vincent-Akpu I. F., Woke G. N. Atarhinyo E., Aharanwa U., Green A. F., Isaac- Jeo 0. Comparative analysis of municipal solid waste (MSW) composition in three local government areas in Rivers State, Nigeria. African Journal of Environ of Environmental Science and Technology Vol. 7(9), pp. 874-881, 2013.

[2] Joanna Pawłat and Henryka D. Stryczewska. Application of Solar Energy in the Processes of Gas,Water and Soil Treatment. Solar Power, Prof. Radu Rugescu (Ed.), 2012, ISBN: 978-953-51-00140, InTech. http://www.intechopen.com

[3] Anabela Oliveira, Enrico Mendes Saggioro, Thelma Pavesi, Josino Costa Moreira and Luis Filipe Vieira Ferreira. Solar Photochemistry for Environmental Remediation - Advanced Oxidation Processes for Industrial Wastewater Treatment, Molecular Photochemistry - Various Aspects, Dr. Satyen Saha (Ed.), 2012. ISBN:978-953-51-0446-9

[4] Melaine, M. E; Alkhaddar, R. M and Phipps, D Sustainable Wastewater Treatment Packaged Plants:Energy Use Minimisation For Small Sites And For Remote Operation.Liverpool Centre for Environmental Technology, Liverpool John Moores University, The Peter Jost Centre, Byrom Street, Liverpool L3 3AF, UK, 2008.
[5] Bogner, J., M. Abdelrafie Ahmed, C. Diaz, A. Faaij, Q. Gao, S. Hashimoto, K. Mareckova, R. Pipatti, T. Zhang,. Waste Management, In Climate Change Mitigation. Contribution of Working Group III to the Fourth Assessment Report of the Intergovernmental Panel on Climate Change [B. Metz, O.R. Davidson, P.R. Bosch, R. Dave, L.A. Meyer (eds)], Cambridge University Press, Cambridge, United Kingdom and New York, NY, USA., 2007.

[6] Ryu Changkook, Potential of Municipal Solid Waste for Renewable Energy Production and Reduction of Greenhouse Gas Emissions in South Korea. J. Air \& Waste Manage. Assoc. 60:176-183, 2010.

[7] Institution of Mechanical Engineers.. Energy from waste, A wasted opportunity? United Kingdom, 2007.

[8] Hoornweg Daniel and Bhada-Tata Perinaz, What a waste; A global review of solid waste management. Urban development and local government unit. World Bank Report, 2012.

[9] Upendra Mani Pradhan, Sustainable Solid Waste Management In A Mountain Ecosystem: Darjeeling, West Bengal, India. Clayton H. Riddell Faculty of Environment Earth and Resources Natural Resources Institute University of Manitoba Winnipeg, Manitoba R3T 2N2, 2008.

[10] Hoornweg , Daniel Laura Thomas and Keshav Verma,. What a Waste : Solid Waste Management in Asia, World Bank, May.1999. Available on line at http://www.worldbank.org/urban/solid_wm/erm/ CWG\%20folder/uwp1.pdf. Assessed February 14th 2015.

[11] Medina Martin. Globalization, Development, and Municipal Solid Waste Management in Third World Cities. 2002. Available online at http://www.gdnet.org/pdf/2002 Awards Medals Winners/ Outstanding Research Development/martin_medina_martinez_paper.pdf > accessed online Dec 18th 2006.

[12] Zerbock Olar. Urban Solid Waste Management: Waste Reduction in Developing Nations. Michigan Technological University, 2003. Accessed Online November 15th 2006. http://www.cee.mtu.edu/ peacecorps/documents.

[13] Zurbrucc Chrish,. Solid Waste Management In Developing Countries. SANDEC/EAWAG, 2003. available on line, accessed February 14th 2015. http://www.sandec.ch/SolidWaste/Documents/04 -SWManagement/Basics of SWM.pdf

[14] Cole Victoria and A. John Sinclair. Measuring the Ecological Footprint of a Himalayan Tourist Center. Mountain Research and Development. 22(2): 132141, 2002.

[15] Duffie and Beckman,. Solar Energy Thermal Processes. John Wiley and Sons Publishing, London, 1974. 
[16] John Dascomb,. Low Cost Concentrating Solar Collector for Steam Generation. Famu-Fsu College of Engineering Florida State University, 2009.

[17] Nwokoye, A.O.C. Solar Energy Technology: Other alternative energy resources and environment. Rex Charles and Patrick Publishing Limited, 2006.

[18] Pawłat Joanna and Henryka D. Stryczewska. Application of Solar Energy in the Processes of Gas,Water and Soil Treatment. Solar Power, 2012. http://www.intechopen.com

[19] Cooper, P.I. "The maximum efficiency of single effect solar stills", Solar Energy 15, 205-207, 1973

[20] Tiwari, G. N.; Singh, H. N.; Tripathi, R. "Present status of solar distillation". Solar Energy 75 (5): 367-373, 2003.

[21] Centres for Disease Control and Prevention (CDCP), 2010.

[22] Meierhofer, R., Landolt, G., Factors supporting the sustained use of solar water disinfection Experiences from a global promotion and dissemination programme, Desalination, Vol. 248, pp. 144-151, 2009.

[23] Acra, A., Karahagopian, Y., Raffoul, Z., Dajani, Z., Disinfection of oral rehydration solutions by sunlight, Lancet, Vol. 316, (No. 8206), pp. 12571258, 1980.

[24] Anabela Oliveira, Enrico Mendes Saggioro, Thelma Pavesi, Josino Costa Moreira and Luis Filipe Vieira Ferreira. Solar Photochemistry for Environmental Remediation - Advanced Oxidation Processes for Industrial Wastewater Treatment, Molecular Photochemistry - Various Aspects, Dr. Satyen Saha (Ed.), 2012. ISBN:978-953-51-0446-9.

[25] Doll, T.E.; Frimmel, F. H.. Removal of selected persistent organic pollutants by heterogeneous photocatalysis in water. Catalysis Today, Vol. 101, pp. 195-202., 2005

[26] Hincapié, M.; Maldonado, M. I.; Oller, I.; Gernjak, W.; Sánchez-Perez, J. A.; Ballestros, M. M.; Malato, S. Solar photocatalytic degradation and detoxification of EU prioritary substances. Catalysis Today, Vol. 101, pp. 203-210, 2005.

[27] CSEM-UAE Innovation Centre LLC. Wastewater Treatment using solar UV radiation, 2013. www. csem-uae.com accessed on $19^{\text {th }}$ July 2015.

[28] Andreozzi R; Caprio V; Insola A.; Marotta, R. Advanced oxidation processes (AOP) for water purification and recovery. Catalysis Today, Vol. 53, No. 1, pp. 51-59, 1999.

[30] Comninellis, C.; Kapalka, A.; Malato, S.; Parsons, S. A.; Poulios, I.; Mantzavinos, D.. Advanced oxidation processes for water treatment: advances and trends for R\&D. Journal of Chemical Technology and Biotechnology, Vol. 83, No. 6, pp. 769-776, 2008.
[31] Matilainen, A.; Sillanpaa, M. Removal of natural organic matter from drinking water by advanced oxidation processes. Chemosphere, Vol. 80, No. 4, pp. 351-365, 2010.

[32] Bahnemann, D.. Photocatalytic detoxification of polluted waters, The Handbook of Environmental Chemistry (Springer-Verlag), Berlin, Germany, 1999.

[33] Safarzadeh-Amiri. A., Bolton J.R., and Cater S.R.. The use of iron in advanced oxidation processes. $A$ Journal of Advanced Oxidation Technologies, 1, 1826, 1996.

[34] Malato, S.; Blanco,J.; Vidal, A,; and Ritcher, C,. Photocatalysis with solar energy at a pilot-plant scale: an overview. Appl. Catal. B: Environ., 37 1, 2002.

[35] Marco, A.; Esplugas, S.; Saum, G.. How and why combine chemical and biological processes for wastewater treatment. Wat. Sci.Technol. 35: 321329, 1997.

[36] Scott, J. P and Ollis, D.F, Integration of chemical and biological oxidation processes for water treatment: Review and recommendations, Environ. Progress, vol 14, pp. 88-103, 1995.

[37] Scott, J. P. and Ollis, D.F, Engineering models of combined chemical and biological processes. J. Environ. Engineering, vol. 122 page 1110 - 1114, 1996.

[38] Parra, S., Malato, S., and Pulgarín, C., New integrated photocatalytic-biological flow system using supported $\mathrm{TiO}_{2}$ and fixed bacteria for the mineralization of isoproturon. Applied Catalysis. B: Environmental, Vol. 36 Issue 2, 20 page 131-144, 2002.

[39] Rodríguez, M., Sarria, V., Espulgas, S., and Pulgarín, C., Photo-Fenton treatment of a biorecalcitrant wastewater generated in textile activities: biodegradability of the photo-treated solution. Journal of Photochem and Photobio. A: Chem. Vol 151 Issues 1-3, 23 pages 129-135, 2002.

[40] Victor Sarria ., Sandra Parra ., Nevenka Alder ., Paul Péringer ., Norberto Benitez., and Cesar Pulgarín., Recent developments in the coupling of photoassisted and aerobic biological processes for the treatment of biorecalcitrant compounds. Catalysis. Today, Vol. 76, Issues 2-4 pages 301-315, 2002.

[41] Gogate, P.R. and Pandit, A.B.. A review of comparative technologies for wastewater treatment II: Hybrid methods. Adv. Environ. Res. 8: 553-561, 2004.

[42] Pera-Titus, M; García-Molina, V; M. A. Baños, J. Giménez and S. Esplugas Degradation of chlorophenols by means of advanced oxidation processes; Appl. Catal. B: Environ. 47: 219- 230, 2004.

Vol. 35, No. 2, April 2016 
[43] Sixto Malato., Waste water treatment by advanced oxidation processes (solar photocatalysis in degradation of industrial contaminants). Innovative Processes and Practices for Wastewater Treatment and Re-use Ankara University, Turkey , 2007.

[44] Guillard, C.; Disdier, J.; Monnet, C.; Dussaud, J.; Malato, S.; Blanco, J.; Maldonado, M.I.; Herrmann, J.M. Solar efficiency of a new deposited titania photocatalyst: chlorophenol, pesticide and dye removal applications. Applied Catalysis B: Environmental, Vol. 46, No. 2, pp. 319-332, 2003.

[45] Burrows, H.D; Canle, L.M; Santaballa, J.A; Steenken, J. Reaction pathways and mechanisms of photodegradation of pesticides. Journal of Photochemistry and Photobiology B: Biology, Vol. 67, No. 2, pp. 71-108, 2002.

[46] Marinas, A.; Guillard, C.; Marinas, J.M.; FernandezAlba, A.; Herrmann, J.M. Photocatalytic degradation of pesticide-acaricide formetanate in aqueous suspension of TiO2. Applied Catalysis B: Environmental, Vol. 34, No. 3, pp. 241-252, 2001.

[47] Peiro, A.M.; Ayllon, J.A.; Peral, J.; Domenech, X.. TiO2 photocatalized degradation of phenol and orthosubstituted phenolic compounds. Applied Catalysis B: Environmental, Vol. 30, pp. 359-367, 2001.

[48] Fu, X.; Zeltner, W.A; Anderson. (1996). Semicondutor Nanoclusters. Elsevier, Vol. 103, pp.445-461, 1996.

[49] Hay, S.O.; Obee, T.N. (1999). The Augmentation of UV Photocatalytic Oxidation with TraceQuantities of Ozone. Advanced Oxidation Technologies, Vol. 4, No.2, pp. 209-218, 1999.

[50] Hashimoto, K.; Wataneble, W. (1999). $\mathrm{TiO}^{2}$ photocatalysis, Fundamentals and Applications, BKC, Tokyo, 1999.

[51] Augugliaro, V., Baiocchi, C ., Bianco,A., Brussino, M. C., García-López, E., Loddo, V., Malato, S., Marcí, G., Palmisano L., and Pramauro, E., Fresenius Environ. Bull., 11 (2002) 459.

[52] Shifu C. and Gengyu, C."Photocatalytic Degradation of Organophosphorus Pesticides Using Floating Photocatalyst TiO2-SiO2/Beads by Sunlight," Solar Energy, Vol. 79, No. 1, pp. 1-9. 2005.
[53] Fujishima, A.; Rao, T.; Tryk, D.A.. Titanium dioxide photocatalysis. Journal Photochemical and Photobiology C: Photochemistry Reviews, Vol. 1, pp. 1-21, 2000.

[54] Pirkanniemi, K.; Sillanpää, M. Heterogeneous water phase catalysis as an environmental view. Chemosphere, Vol. 48, pp. 1047-1060, 2002

[55] Malato, S., Blanco, J., Vidal, A., Alarcón, D., Maldonado, M. I., Cáceres, J. and Gernjak, W. Applied studies in solar photocatalytic detoxification: an overview. Solar Energy, 75 (4), 329-336., 2003.

[56] Fernández-Alba, A. R., Hernando, D., Agüera, A., Cáceres, J., and Malato, S. "Toxicity Assays: A Way for Evaluating AOPs Efficiency, " Water Res., 36: 42 $-55 ., 2002$.

[57] Sarria, V., Parra, S., Adler, N., Péringer, P., Benitez, N., and Pulgarin, C. Catalysis Catalytic activity of commercial of TiO 2 powders for the abatement of the bacteria (E. coli) under solar simulated light: Today, 76301 (2), 301-315, 2002.

[58] Lede, J., Solar thermochemical conversion of biomass, Solar Energy, Vol. 65, pp. 3-13, 1999.

[59] Perkins, C., Weimer, A., Solar-thermal production of renewable hydrogen, AIChE Journal, Vol. 55, pp. 286-293, 2009.

[60] Melchior, T., Perkins, C., Lichty, P., Weimer, A., Steinfeld, A., Solar-driven biochar gasification in a particle-flow reactor, Chemical Engineering and Processing, Vol. 48, pp. 1279-1287, 2009.

[61] Piatkowski, N., Steinfeld, A., Solar-driven coal gasification in a thermally irradiated packed-bed reactor, Energy Fuels, Vol. 22, pp. 2043-2052, 2008.

[62] Hongwei Wu., Solar thermal pyrolysis. Online presentation from Curtin University of Technology, Perth, Australia. www.curtin.edu.au accessed on July 2013.

[63] Kostantinos Moustakas and Maria Loizidou. Solid waste management through the application of thermal methods, waste management, Er Sunil Kumar (Ed.), 2010. ISBN: 978-953-7619-84-8. Intech. http: \\www.intechopen.com

[64] Davidson, H. Jane, Solar energy powered biomass gasifier for syngas production. School of mechanical engineering, University of Minnesota. 2014. 